\title{
ANALISIS BRAND IMAGE DAN BRAND AWARNESS PUPUK BIO ORGANIK (Studi pada Petani Pengguna Pupuk Merek “POMI" di Kota Batu)
}

\author{
Agustina Shinta $^{1}$, Abdul Wahib Muhaimin ${ }^{1}$, Fikriah $^{2}$ dan Palupi ${ }^{2}$ \\ 1 Dosen Jurusan Agribisnis, Fakultas Pertanian, Universitas Brawijaya \\ 2 Alumni Jurusan Agribisnis, Fakultas Pertanian, Universitas Brawijaya \\ Email: shint4_71ub@yahoo.com
}

\begin{abstract}
This study examines brand image and brand awareness based on selected attributes of bio-organic fertilizer product brand "Pomi". The purpose of this study is to analyze brand image, the attributes of bio-organic fertilizer product brand "Pomi" and analyze the brand awareness. Attributes are considered peasants were analyzed by using Cochran $Q$, then is used to measure brand awareness. Determination of levels of awareness of the brand and brand image owned by the respondent is based on the total score from the Likert scale values obtained in the overall indicator. The result of brand image is based on three variables: Variable of strength, the average value (mean) overall strength variable is 4.26. Variable of uniqueness, the average value (mean) overall for the uniqueness variable is 4.11. Favorable variables, the average value (mean) overall favorable variables is 4.25 . Overall average score (mean) based on brand image variables (strength, uniqueness, and favorable) Bio Organic fertilizer brand "Pomi" is 4.21. The average value (mean) indicates the positive brand image, because the average (mean) in more than 3, then the perceived brand image of farmers to fertilizer Bio Organics brand "Pomi" is positive. And The results showed brand awareness of farmers in the position of brand recall as many as $69 \%$ were farmers place the bio-organic fertilizer brand "Pomi" in the second position in the pyramid of brand awareness.
\end{abstract}

Keyword: consumer behavior, brand awareness, brand image

\begin{abstract}
Abstrak: Penelitian ini mengkaji citra merek dan kesadaran merek berdasarkan atribut terpilih produk pupuk bio organik merek "Pomi". Tujuan penelitian ini adalah menganalisis citra merek, atribut produk pupuk bio organik merek "Pomi" dan menganalisis kesadaran merek. Metode analisis data digunakan skala likert dan cohran Q test. Hasil penelitian untuk citra merek didasarkan pada tiga variable secara keseluruhan rata-rata 4,21 yang artinya bahwa ada indikasi positif pada citra merek pupuk "Pomi", sedangkan masing-masing variable dapat dijelaskan sebagai berikut : variable kekuatan bernilai rata-rata 4,26, variable keunikan bernilai rata-rata 4,11, dan variable favourable bernilai rata-rata 4,25 , Untuk kesadaran merek petani berada pada posisi brand recall yaitu sebanyak 69\% menempatkan pupuk bio organik merek "Pomi" pada posisi kedua dalam piramida kesadaran merek. Hal ini menunjukkan kesadaran merek petani terhadap sudah cukup tinggi meskipun tidak berada pada posisi top of mind.
\end{abstract}

Kata kunci: perilaku konsumen, kesadaran merek, citra merek

\section{PENDAHULUAN}

Persoalan merek menjadi salah satu persoalan yang harus dipantau secara terus-menerus oleh setiap perusahaan. Merek-merek yang kuat, teruji, dan bernilai tinggi terbukti tidak hanya sukses mengalahkan hitungan-hitungan rasional, tetapi juga canggih mengolah sisi-sisi emosional konsumen. Merek bisa memiliki nilai tinggi karena ada brand building activity 
yang bukan sekadar berdasarkan komunikasi, tetapi merupakan segala macam usaha lain untuk memperkuat merek tersebut. Akibat dari brand building activity, menimbulkan brand signaling, dimana ada tanda-tanda yang dikirim kepada konsumen dari sebuah merk untuk menarik konsumen berespon.

Merek akan mempunyai reputasi jika merek tersebut memiliki kualitas dan karisma. Agar memiliki karisma, merek harus mempunyai aura, memiliki konsistensi, kualitasnya harus dijaga dari waktu ke waktu, selain itu tentunya juga harus mempunyai kredibilitas. Agar tampil menjadi yang terbaik, tentu suatu merek harus terlihat menarik di pasar hingga mampu membuat konsumen tertarik untuk membelinya. Agar terlihat menarik, merek tersebut harus memiliki costumer value jauh di atas merek-merek yang lain. Selain itu, harus mampu meningkatkan keterlibatan emosi pelanggan sehingga pelanggan mempunyai ikatan dan keyakinan terhadap sebuah merek.

Dalam kondisi persaingan usaha yang semakin ketat, perusahaan perlu memanfaatkan sumber dayanya secara optimal, termasuk berusaha menciptakan atau melakukan rekayasa yang dapat mempengaruhi persepsi konsumen, misalnya melalui citra merek produk. Pada saat ini, pelanggan atau konsumen tidak hanya melihat sesuatu produk dari harga dan kualitas, tetapi juga melihat dari brand image yang melekat pada produk yang dikonsumsi. Perusahaan yang mempunyai citra merek yang kuat mempunyai alternatif untuk bersaing pada tingkat harga dan spesifikasi produk (Aaker, 1992). Dengan memiliki citra merek yang kuat perusahaan dapat tetap bersaing, merebut dan bahkan memenangkan persaingan pasar.

Menurut Low dan Lamb Jr (2000) citra merek adalah persepsi tentang suatu merek sebagai refleksi asosiasi merek yang terbentuk dalam ingatan konsumen. Bagian dari asosiasi merek adalah persepsi kualitas dan sikap terhadap merek. Sedangkan identifikasi asosiasi merek dapat didasarkan dengan menyatakan tentang asosiasinya, mengurangi penyensoran tanggapan, dan validasi laporan (Supphellen, 2000). Tetapi asosiasi merek sebagai bagian dari katagorisasi merek juga dapat ditentukan dengan menggunakan ketidakpastian sebagai dimensi intrinsik, sehingga dapat diperoleh segmen dan struktur pasar, sementara ketidakpastian tersebut dapat berupa pikiran terhadap merek individu, merek relatif dan unsur persepsi resiko (Davis, 2002).

Membangun persepsi dapat dilakukan melalui jalur merek dan memahami perilaku merek. Merek yang prestisius dapat disebut memiliki ekuitas merek yang kuat. Ekuitas merek merupakan aset dan liabilitas merek. Agar aset dan liabilitas mendasari ekuitas merek, maka aset dan liabilitas merek harus berhubungan dengan nama atau sebuah simbol sehingga jika dilakukan perubahan terhadap nama dan simbol merek, beberapa atau semua aset liabilitas yang menjadi dasar ekuitas merek akan berubah pula. Suatu produk dengan ekuitas merek yang kuat dapat membentuk landasan merek yang kuat dan mampu mengembangkan keberadaan suatu merek dalam persaingan apa pun dalam jangka waktu yang lama (Durianto dkk., 2004). Dengan semakin banyaknya jumlah pesaing di pasar, meningkat pula ketajaman persaingan di antara merek-merek yang beroperasi di pasar dan hanya merek yang memiliki ekuitas merek yang kuat yang akan tetap mampu bersaing, merebut, dan menguasai pasar. Karena itu, pengetahuan tentang variabel-variabel ekuitas merek, salah satunya adalah kesadaran merek (brand awareness) sangat diperlukan untuk menyusun langkah strategis dalam meningkatkan eksistensi merek.

Menurut Aaker dalam Simamora (2001), kesadaran merek adalah kemampuan seseorang untuk mengenali atau mengingat kembali bahwa suatu merek merupakan bagian dari kategori produk tertentu. Sedangkan menurut Durianto dkk (2001), kesadaran merek merupakan kesanggupan seorang calon pembeli untuk mengenali, mengingat kembali suatu merek sebagai bagian dari suatu kategori produk tertentu.

Tidak terkecuali produk pertanian, perusahaan yang bergerak di sector tersebut sangat mementingkan citra merek yang positif. Citra merek yang positif dan kuat akan memiliki ekuitas merek yang akan tetap mampu bersaing dan merebut pasar. Salah satu variable dari ekuitas merek adalah kesadaran merek dalam hal ini konsumen petani di dalam membeli produk pertanian. Dalam kegiatan menghasilkan produk pertanian, petani tidak lepas dari penggunaan pupuk. Sebelum 
mengenal pupuk kimia, petani menggunakan kearifan lokal seperti pemuliaan benih secara alami, penanaman bergilir dan penggunaan pupuk alami. Hasil yang di dapatkan bagus, selain itu penyakit tanaman belum seberapa banyak dan aneh-aneh, tanah masih gembur dan subur (Anonymous ${ }^{\text {a }}$, 2010).

Istilah pupuk hayati atau nama lainnya pupuk Bio Organik digunakan sebagai nama kolektif untuk semua kelompok fungsional mikroba tanah yang dapat berfungsi sebagai penyedia hara dalam tanah, sehingga dapat tersedia bagi tanaman. Pupuk hayati atau pupuk Bio Organik didefinisikan sebagai inokulan berbahan aktif organisme hidup yang berfungsi untuk menghambat hara tertentu atau memfasilitasi tersedianya hara dalam tanah bagi tanaman. FNCA Biofertilizer Project Group (2006) mengusulkan definisi pupuk hayati sebagai substans yang mengandung mikroorganisme hidup yang mengkolonisasi rizosfir atau bagian dalam tanaman dan memacu pertumbuhan dengan jalan meningkatkan pasokan ketersediaan hara primer dan/atau stimulus pertumbuhan tanaman target, bila dipakai pada benih, permukaan tanaman, atau tanah. Peran pupuk Bio Organik adalah untuk meningkatkan produktivitas lahan dan produksi pertanian.

Bahan baku dalam pembuatan pupuk Bio Organik adalah Ethanol, salah satu penghasil Ethanol di Indonesia adalah PT. Indo Acidatama Tbk . PT. Indo Acidatama Tbk mengeluarkan dan memproduksi pupuk Bio Organik dengan merek "Pomi". Merek "Pomi" terbagi menjadi beberapa jenis yaitu Pomi merah, hijau, kuning dan coklat. Pomi merah untuk tanaman bawang merah, bawang putih, tomat, cabe, semangka, melon, serta buahbuahan dan sebagainya. Pomi kuning untuk tanaman padi, jagung, kedelai dan kacangkacangan. Pomi hijau untuk sayur-sayuran dan Pomi coklat untuk tanaman perkebunan seperti karet, sawit, dan sebagainya (Anonymous, 2009). Keunggulan "Pomi" ini adalah diproduksi melalui proses bioteknologi bahanbahan organik, terbuat dari $100 \%$ bahan organik, tidak ada tanggal kadaluarsa, harganya terjangkau oleh petani, terdapat 7 mikroba yang berguna untuk meningkatkan hasil panen.

Dengan adanya berbagai merek pupuk Bio Organik di pasaran sehingga menimbulkan berbagai macam pilihan merek bagi konsumen yang akan membeli pupuk Bio Organik. Dalam kondisi persaingan usaha yang semakin ketat, perusahaan perlu memanfaatkan sumber dayanya dengan optimal, termasuk berusaha menciptakan atau melakukan rekayasa yang dapat mempengaruhi persepsi konsumen, misalnya melalui citra merek produk. Pada saat ini, pelanggan atau konsumen tidak hanya melihat sesuatu produk dari harga dan kualitas, tetapi juga melihat dari brand image yang melekat pada produk yang dikonsumsi. Perusahaan yang mempunyai citra merek yang kuat mempunyai alternatif untuk bersaing pada tingkat harga dan spesifikasi produk (Aaker, 1992). Dengan memiliki citra merek (brand image) dan kesadaran merek (brand awareness) yang kuat perusahaan dapat tetap bersaing, merebut dan bahkan memenangkan persaingan pasar.

Berdasarkan uraian diatas, maka penelitian ini difokuskan pada brand image dan brand awareness pupuk Bio Organik merek "Pomi yang dilakukan di Dusun Junwatu, Desa Junrejo, Kecamatan Junrejo, Kota Batu.

\section{Tujuan Penelitian}

Tujuan dari penelitian ini adalah:

1. Untuk menganalisis brand image petani terhadap pupuk Bio Organik merek "Pomi"

2. Untuk menganalisis brand awareness berdasarkan atribut terpilih produk pupuk bio organik merek "Pomi".

\section{Metode Penelitian}

Metode penentuan lokasi penelitian ditentukan secara sengaja (purposive). Lokasi penelitian di Dusun Junwatu, Desa Junrejo, Kecamatan Junrejo, Kota Batu. Teknik penentuan sampel yang digunakan yaitu Purposive Sampling yang merupakan teknik pengambilan sampling yang secara sengaja karena sampel dipilih berdasarkan pertimbangan bahwa responden pernah menggunakan pupuk Bio Organik merek "Pomi" di Dusun Junwatu, Desa Junrejo Kecamatan Junrejo, Kota Batu. Disebabkan populasi petani yang menggunakan pupuk Bio Organik "Pomi" tidak diketahui, maka penentuan jumlah sampel diperoleh dengan pendekatan Malhotra (1996), bahwa syarat jumlah sampel yang diambil umtuk penelitian memiliki kriteria tertentu, minimal $4-5$ kali jumlah atribut / variabel yang digunakan dalam 
penelitian. Sehingga apabila jumlah atribut yang digunakan dalam penelitian adalah sebanyak 11 maka jumlah sampelnya adalah 55 petani.

\section{Pengukuran Variabel}

1) Pengukuran brand image dapat didasarkan pada tiga variabel yaitu :

a. Kekuatan (strength)

Kekuatan disini berkaitan dengan seberapa kuat hubungan yang mampu diciptakan oleh merek dengan konsumen. Biasanya pengukuran kekuatan ini dapat dibentuk melalui pengalaman masa lalu, harga, kualitas, rekomendasi perorangan, iklan, dan lain-lain.

b. Keunikan (Uniqueness)

Uniqueness adalah kemampuan untuk membedakan sebuah merek diantara merekmerek lainnya. Kesan unik ini muncul dari atribut produk, yang berarti terdapat diferensiasi antara produk yang satu dengan yang lainnya. Terdapat dalam kelompok unik ini adalah variasi layanan yang bisa diberikan sebuah produk, variasi harga yang bersangkutan, maupun diferensiasi dari penampilan fisik sebuah produk.

c. Favorable

Favorable mengarah kepada kemampuan merek tersebut untuk mudah diingat oleh konsumen. Termasuk dalam kelompok favorable ini antara lain : kemudahan merek untuk diucapkan, kemampuan merek untuk mudah diingat oleh konsumen, maupun kesesuaian antara kesan merek di benak konsumen dengan citra yang diinginkan perusahaan atas merek yang bersangkutan.

\section{2) Pengukuran brand awareness}

Menurut Susanto dan Wijanarko (2004) kesadaran merek berada pada rentang antara perasaan yang tak pasti terhadap pengenalan suatu merek sampai perasaan yakin bahwa produk tersebut merupakan satu-satunya dalam kelas produk yang bersangkutan. Variabel brand awareness dibagi menjadi sub-sub variabel yang secara urut (Rangkuti, 2004) sebagai berikut:

\section{Top of Mind (puncak pikiran)}

Yaitu merek produk yang pertama kali disebutkan oleh konsumen secara spontan dan menempati tempat khusus atau istemewa dibenak konsumen.
2. Brand recall (Pengingatan kembali terhadap merek)

Mencerminkan merek-merek apa saja yang diingat konsumen setelah menyebutkan merek yang pertama kali disebut. Dimana merek-merek yang disebutkan kedua, ketiga dan seterusnya merupakan merek yang menempati brand recall dalam benak konsumen.

3. Brand recognition (Pengenalan merek)

Merupakan tingkat minimal dari kesadaran merek yang merupakan pengenalan merek dengan bantuan, misalnya dengan bantuan daftar merek, daftar gambar, atau cap merek. Dan merek yang masuk dalam ingatan konsumen disebut brand recognition.

4. Unaware of brand (tidak menyadari merek)

Merupakan tingkatan merek yang paling rendah dalam piramida brand awareness, dimana konsumen tidak menyadari akan eksistensi suatu merek.

\section{METODE ANALISA DATA}

\section{Analisis brand image}

Aspek yang ingin diukur dalam penelitian ini adalah variabel dan atribut. Dalam penelitian ini, variabelnya adalah strength, uniqueness dan favorable.. Pengukuran variabel dilakukan melalui penilaian responden terhadap indikatorindikator. Sedangkan atribut yang digunakan meliputi variasi layanan, pengalaman masa lalu, harga, kesesuaian kesan merek pada benak konsumen, Iklan, rekomendasi perorangan, kemudahan merek untuk diucapkan, diferensiasi penampilan fisik produk, kemampuan merek untuk mudah diingat, kualitas, variasi harga. Untuk menganalisis brand image mengenai pupuk Bio Organik merek "Pomi", maka dibutuhkan suatu skala pengukuran. Skala pengukuran yang digunakan adalah Skala Likert. Skala Likert disebut juga summated rating scale dan menghasilkan data interval (Simamora, 2005). Instrumen penelitian adalah dengan menggunakan kuesioner. Jawaban setiap item instrumen ini memiliki gradasi tertinggi (sangat positif) hingga terendah (sangat negatif). Untuk keperluan analisis secara kuantitatif maka jawaban diberi skor. Setelah itu, tahap selanjutnya adalah mencari nilai rata-rata (mean) dan yang terakhir menginterpretasikannya. untuk mengukur 
brand image pupuk Bio Organik merek "POMI" yang didasarkan dari variabel-variabel brand image (strength, uniqueness, dan favorable) ini dapat menggunakan ketentuan :

a. Jika rata-rata (mean) responden dibawah 3 maka brand image pupuk Bio Organik merek "POMI" adalah dianggap negatif.

b. Jika rata-rata (mean) responden diatas 3 maka brand image pupuk Bio Organik merek "POMI" adalah dianggap positif.

\section{Analisis brand awarness}

Pengukuran atribut produk pupuk bio organik merek "Pomi" dilakukan dengan menggunakan uji Cochran $Q$ untuk mendapatkan atribut-atribut yang dipertimbangkan oleh petani. Selanjutnya atribut-atribut terpilih yang dipertimbangkan oleh petani digunakan untuk mengukur kesadaran merek produk pupuk bio organik merek "Pomi". Pengukuran terhadap atributatribut yang digunakan untuk menganalisis kesadaran merek diukur dengan skala likert (15). Adapun jumlah posisi pupuk bio organik merek "Pomi" dalam benak petani diperoleh dari penjumlahan skor yang didapatkan dari skala likert tersebut yang dimasukkan kedalam interval total skor. Dengan demikian dapat diketahui apakah petani yang ada telah memiliki tingkatan kesadaran merek yang paling tinggi yaitu top of mind (puncak pikran), brand recall (pengingat kembali terhadap merek), brand recognition (pengenalan merek), dan unaware of brand (tidak menyadari merek).

Menurut teori terdapat 4 kategori tingkatan kesadaran merek. Petani dikatakan memiliki kesadaran merek paling rendah (unaware of brand) jika skor yang diperoleh berada pada interval $10-20$. Hal ini menunjukkan bahwa petani tidak dapat mengenali merek "Pomi" meskipun dengan menggunakan alat bantu. Tingkatan brand recognition jika skor yang diperoleh berada pada interval nilai 21 - 31 yang berarti bahwa petani akan dapat mengingat merek "Pomi" dengan bantuan yang diberikan. Tingkatan brand recall jika skor yang diperoleh berada pada pada interval nilai 32 - 42 yang berarti bahwa petani dapat mengingat merek "Pomi" dengan baik tanpa bantuan. Tingkatan top of mind yaitu tingkatan tertinggi dalam piramida kesadaran merek jika skor yang diperoleh berada pada interval > 42 yang berarti bahwa petani sangat mengingat semua elemen yang dimiliki oleh merek "Pomi".

\section{HASIL DAN PEMBAHASAN}

Variabel strength dalam pengukuran brand image ini menjelaskan mengenai berbagai keunggulan-keunggulan yang dimiliki pupuk Bio Organik merek "Pomi" yang bersifat fisik. Keunggulan pupuk Bio Organik merek "Pomi" ini berdasarkan atribut-atribut fisik atas merek yang bersangkutan sehingga bisa dianggap sebuah kelebihan.Secara keseluruhan, nilai rata-rata (mean) untuk variabel strength ini adalah sebesar 4,26. Adapun interpretasi secara keseluruhan unuk variabel strength ini adalah responden menyatakan sangat setuju terhadap pertanyaan yang berisi indikator-indikator variabel strength. Nilai rata-rata (mean) dari variabel strength ini dapat memberikan kontribusi yang besar dalam pembentukan image positif bagi Pupuk Bio Organik merek "Pomi", karena nilai seperti telah disebutkan sebelumnya jika nilai rata-rata (mean) diatas 3 maka brand image maka brand image dianggap positif .

Variabel Uniqueness ini mengarah pada kemampuan untuk membedakan sebuah merek diantara merek pupuk Bio Organik merek lain. Kesan unik ini muncul dari atribut produk. Kesan unik ini berarti terdapat diferensiasi antara produk pupuk Bio Organik yang satu dengan yang lainnya. Adapun indikator dari variabel Uniqueness ini adalah : Pomi diproduksi melalui proses bioteknologi bahanbahan organik, Pomi tidak memiliki tanggal kadaluarsa dan indikator yang terakhir yaitu Pomi adalah Pupuk Bio Organik Plus dan bukan sekedar pupuk biasa karena terbuat dari 7 mikroba yang berfungsi menyuburkan tanaman dan meningkatkan hasil panen. Secara keseluruhan, nilai rata-rata (mean) untuk variabel uniqueness ini adalah sebesar 4,11. Adapun interpretasi secara keseluruhan unuk variabel uniqueness ini adalah responden menyatakan setuju terhadap pertanyaan yang berisi indikator-indikator variabel uniqueness. Nilai ini menunjukkan bahwa variabel uniqueness ini memberikan kontribusi yang besar dalam pembentukan image positif bagi Pupuk Bio Organik merek "Pomi", karena 
seperti telah disebutkan sebelumnya jika nilai rata-rata (mean) diatas 3 maka brand image adalah dianggap positif Pengukuran brand image dari perspektif favorable ini mengarah kepada kemampuan merek tersebut untuk mudah diingat oleh konsumen berdasarkan pada indikator seperti berikut ini:

1. PT. Indo Acidatama merupakan perusahaan yang memproduksi pupuk Bio Organik Pomi.

2. Desain logo dan gambar yang mudah dikenali dan diingat oleh konsumen.

3. Nama merek "Pomi " yang mudah diingat dan mudah diucapkan.

Secara keseluruhan, nilai rata-rata (mean) untuk variabel favorable adalah sebesar 4,25. Adapun interpretasi secara keseluruhan unuk variabel favorable ini adalah responden menyatakan sangat setuju terhadap pertanyaan yang berisi indikator-indikator variabel favorable. Nilai ini menunjukkan bahwa variabel favorable imemberikan kontribusi yang besar dalam pembentukan image positif bagi Pupuk Bio Organik merek "Pomi”, karena nilai rata-rata (mean) seperti telah disebutkan sebelumnya jika nilai rata-rata (mean) diatas 3 maka brand image adalah dianggap positif

Dari ketiga variable diatas, Nilai rata-rata (mean) secara keseluruhan dari variabel yang dugunakan untuk mengukur brand image (strength, uniqueness, dan favorable) adalah 4,21. Nilai rata-rata (mean) ini mendukung positifnya brand image petani terhadap Pupuk Bio Organik merek "Pomi". Adapun interpretasi secara keseluruhan unuk variabel strength, uniqueness dan favorable ini adalah responden menyatakan sangat setuju terhadap pertanyaan yang berisi indikator-indikator variabel strength, uniqueness dan favorable.

\section{Hasil Analisis Brand Awarness}

Dari 12 atribut produk yang diuji, atribut-atribut yang dipertimbangkan oleh petani terhadap produk pupuk bio organik merek "Pomi" hanya ada 10 atribut. Atribut tersebut antara lain yaitu harga, mudah diucapkan, mudah diingat, kualitas, kadaluarsa, kandungan pupuk, bentuk kemasan, label, ketersedian produk, dan jenis promosi.

Pengukurannya menggunakan skala likert, selanjutnya untuk penetapan tingkatan kesadaran merek yang dimiliki responden dilakukan berdasarkan jumlah skor dari nilai skala likert yang diperoleh pada keseluruhan indikator

Tabel 1. Tingkatan Kesadaran Merek Berdasarkan Jumlah Responden

\begin{tabular}{cccc}
\hline No & $\begin{array}{l}\text { Tingkatan } \\
\text { Kesadaran } \\
\text { Merek }\end{array}$ & Jumlah & $\begin{array}{c}\text { Persentase } \\
(\%)\end{array}$ \\
\hline 1 & Top Ofmind & 6 & 11 \\
2 & $\begin{array}{l}\text { Brand Recall } \\
\text { Brand }\end{array}$ & 38 & 69 \\
3 & 11 & 20 \\
& $\begin{array}{l}\text { Recognition } \\
\text { Unaware Of } \\
\text { Brand }\end{array}$ & 0 & 0 \\
\hline & Total & 55 & 100 \\
\hline
\end{tabular}

Sumber : Data Primer Diolah (2010)

Tabel 1 menunjukan bahwa pupuk bio organik "Pomi" merupakan brand recall (pengingat kembali merek) dengan memperoleh $69 \%$ atau sebanyak 38 responden. Selanjutnya sebanyak $20 \%$ atau sebanyak 11 orang responden yang menempatkan pupuk bio organik merek "Pomi" pada posisi brand recognition. Pada posisi top of mind terdapat 6 orang responden (11\%) yang menempatkan pupuk bio organik merek "Pomi" di benaknya. Sedangkan pada posisi unaware of brand, tidak ada satu orang respondenpun yang tidak mengetahui keberadaan pupuk bio organik merek "Pomi".

Tabel 2. Tingkat Kesadaran Merek Berdasarkan Atribut Terpilih

\begin{tabular}{cll}
\hline No & \multicolumn{1}{c}{ Atribut } & Tingkatan Kesadaran Merek \\
\hline 1 & Harga & Brand Recall \\
2 & Mudah Diucapkan & Top OfMind \\
3 & Mudah Diingat & Top OfMind \\
4 & Kualitas & Top OfMind \\
5 & Kadaluarsa & Brand Recall \\
6 & Kandungan Pupuk & Brand Recognition \\
7 & Bentuk Kemasan & Top OfMind \\
8 & Label & Brand Recognition \\
9 & Ketersediaan Produk & Brand Recall \\
10 & Jenis Promosi & Brand Recall \\
\hline
\end{tabular}

Sumber : Data Primer Diolah (2010) 
Tabel 2 menunjukkan bahwa atribut produk yang menempati posisi top of mind yaitu mudah diucapkan, mudah diingat, kualitas, dan bentuk kemasan. Hal ini menunjukkan bahwa atribut-atribut tersebut tersimpan dalam benak konsumen. Selanjutnya atribut yang menempati posisi brand recall yaitu harga, kadaluarsa, ketersediaan produk dan jenis promosi. Hal ini menunjukkan bahwa atribut-atribut tersebut mampu diingat oleh petani tanpa bantuan meskipun tidak secara spontan. Sedangkan atribut yang menempati posisi brand recognition yaitu kandungan produk dan label.

\section{KESIMPULAN DAN SARAN}

1. Analisis brand image didasarkan atas 3 variabel yaitu :

a. Variabel strength, nilai rata-rata (mean) keseluruhan untuk variabel strength adalah 4,26

b. Variabel uniqueness, nilai rata-rata (mean) keseluruhan untuk variabel uniqueness adalah 4,11

c. Variabel favorable, nilai rata-rata (mean) keseluruhan untuk variabel favorable adalah 4,25 .

Secara keseluruhan nilai rata-rata (mean) berdasarkan variabel brand image (strenght, uniqueness, dan favorable) pupuk Bio Organik merek "Pomi" adalah 4,21. Nilai rata-rata (mean) ini menunjukkan positifnya brand image, karena nilai rata-rata (mean) in lebih dari 3, maka dianggap brand image petani terhadap pupuk Bio Organik merek "Pomi" adalah positif.

2. Atribut-atribut produk pupuk bio organik merek "Pomi" yang dipertimbangkan oleh konsumen antara lain yaitu harga, mudah diucapkan, mudah diingat, kualitas, kadaluarsa, kandungan pupuk, bentuk kemasan, label, ketersediaan produk, dan jenis promosi. Tingkatan kesadaran merek pupuk bio organik "Pomi" yang diukur berdasarkan atribut terpilih yaitu menempati posisi brand recall (pengingatan kembali terhadap merek) yaitu sebanyak 38 responden $(69 \%)$. Hal ini menunjukkan bahwa kesadaran merek petani terhadap pupuk bio organik merek "Pomi" sudah cukup tinggi meskipun tidak menempati posisi top of mind (puncak pikiran) karena terdapat 38 responden yang mampu mengingat pupuk bio organik merek "Pomi" tanpa bantuan. Selanjutnya, untuk atributatribut yang menempati posisi top of mind yaitu mudah diucapkan, mudah diingat, kualitas, dan bentuk kemasan. Atribut harga, kadaluarsa, ketersediaan produk, dan jenis promosi menempati posisi brand recall. Sedangkan yang menempati posisi brand recognition yaitu kandungan pupuk dan label.

\section{DAFTAR PUSTAKA}

Aaker, David. A.1992. Managing the Most Important Asset: Brand Equity Planning Review, 20 (5): 56-60

Anonymous. 2009. PT. INDO ACIDATAMA. http://www.acidatama.co.id/ profil.php. Aksess Tanggal 10 September 2010.

Davis, D.F. (2002), "Fuzzy sets, Uncertainty, and Brand Associations, " American

Marketing Associations, 13: 312-319.

FNCA Biofertilizer Project Group. 2006. Biofertilizer Manual. Forum for Nuclear Cooperation in Asia (FNCA). Japan Atomic Industrial Forum, Tokyo. Aksess tanggal 11 Juni 2010.

Low , G. S., \& Lamb , C. W. Jr. 2000. The Measurement and Dimensionality of brand Association, Journal of Product and Brand Management, Volume 9 (no.6)., pp 350-368. 18 Agustus 2006. http://www.brandchannel.com/images/pa pers/taxonomy.pdf. Aksess Tanggal 11 September 2010.

Lamb, Charles W, Hair, Joseph F, and McDaniel, Carl. 2001. Pemasaran. Salemba Empat. Jakarta.

Malhotra, Nareshk. 1996. Marketing Research and Applied Oriented. Prentice Hall. Upper Saddle River. New Jersey.

Rangkuti, Freddy. 2004. The Power of Brand. PT. Gramedia Pustaka Utama. Jakarta. 
Simamora, Bilson. 2002. Aura Merek. PT.Gramedia Pustaka Utama. Jakarta.

2002. Panduan Riset Perilaku Konsumen. PT. Gramedia Pustaka Utama. Jakarta.

Supphellen, M. (2000), "Understanding Core Brand Equity: Guideliness for in-depth Elicitation of Brand Associations,"
International Journal of Market Research, 42 (3): 319-331.

Vina Mustika Sari dan Kartika Kurniawan. 2007. Analisa Brand Image Konsumen di Kediri Terhadap Tahu Lym Paska Isu Formalin dan Dampaknya Terhadap Kesediaan Konsumen Untuk Membeli Kembali. Universitas Kristen Petra. Surabaya. 